\title{
Exploring Subseafloor Life with the Integrated Ocean Drilling Program
}

\author{
by Steven D'Hondt, Fumio Inagaki, Timothy Ferdelman, Bo Barker Jørgensen, \\ Kenji Kato, Paul Kemp, Patricia Sobecky, Mitchell Sogin and Ken Takai
}

\section{Introduction}

Deep drilling of marine sediments and igneous crust offers a unique opportunity to explore how life persists and evolves in the Earth's deepest subsurface ecosystems. Resource availability deep beneath the seafloor may impose constraints on microbial growth and dispersal patterns that differ greatly from those in the surface world. Processes that mediate microbial evolution and diversity may also be very different in these habitats, which approach and probably pass the extreme limits of life. Communities in parts of the deep subsurface may resemble primordial microbial ecosystems, and may serve as analogues of life on other planetary bodies, such as Mars or Europa, that have or once had water.

Cell concentration estimates suggest remarkably abundant microbial populations in subseafloor sediments (Whitman et al., 1998; Parkes et al., 2000), but current models do not account for their possible impact on global biogeochemical cycling. Furthermore, we lack fundamental knowledge of microbial community composition, diversity, distribution, and metabolism in subseafloor environments. Exploration of this system presents a rich opportunity to understand microbial communities at Earth's extremes. Microbes in different subseafloor environments often encounter and must survive conditions of high pressure, high temperature, and extreme starvation. The limits of subsurface life are not yet known in terms of any environmental properties, including depth, temperature, energy availability, and geologic age; however, it is known that subseafloor microbes play a significant role in chemical reactions that were previously thought to have been abiotic, including iron and sulfur cycling as well as ethane and propane generation (Hinrichs et al., 2006). Some subseafloor communities probably derive food (electron donors) without sunlight (Jørgensen and D’Hondt, 2006). In addition, while molecular analyses and cultivation experiments demonstrate a surprisingly high diversity of microbial life in the subseafloor (Reed et al., 2002; Inagaki et al., 2003, 2006; Teske, 2006; Webster et al., 2006; Batzke et al., 2007), the relative abundances and roles of Archaea, Bacteria, Eukarya, and viruses remain largely unknown. In short, subseafloor life constitutes one of the least explored biomes on Earth and deserves intense exploration.

The Integrated Ocean Drilling Program (IODP) provides researchers with tremendous opportunities to better under- stand the abundance, activity, diversity, and limits of deep subseafloor microbial communities through drilling expeditions. A workshop titled "Exploration of Subseafloor Life with IODP" was convened in October 2006 to solicit recommendations and guidance from a broad community of scientists and to address scientific issues and technical challenges for exploring microbial life in the deep subseafloor. The ninety diverse workshop participants included molecular biologists, microbiologists, microbial ecologists, geologists, biogeochemists, drilling experts, and engineers.

Breakout sessions were focused on four key scientific areas: (1) biogeography, (2) genes, cells, populations, and communities, (3) habitability, and (4) technology. The principal conclusions of these breakout groups were as follows:

Biogeography: Four aspects of biogeography were considered particularly important. The first is a thorough characterization of the full range of deep subsurface habitats and their microbiota including deep subseafloor communities that are controlled by surface inputs (for example, via sediment accumulation) and their changes with age and depth. They also include microbial communities that derive their energy from non-photosynthetic processes (e.g., thermogenesis of organic compounds, subduction zone processes, serpentinization, and radiolysis of water) and basaltic environments deep beneath the seafloor. The last is potentially Earth's largest habitat by volume, but its significance as a habitat for microbial life has yet to be confirmed. Second, spatial and temporal controls on diversity need to be explored through (1) detailed fine-scale analysis of appropriately stored cores from previously drilled holes, (2) new drilling expeditions that target contrasting sedimentary environments, and (3) institution of deep subseafloor microbial observatories. Such studies will identify evolutionary controls on diversity and go beyond current surveys of biodiversity changes with depth and habitat. Third, we also need to know the mechanisms and rates of evolution under potentially slow growth, low predation, and severe energy limitation conditions. Do these situations select for novel metabolic and life history strategies? Finally, the extent to which the deep biosphere is generally connected or isolated from the surface biosphere is unclear. Is there a subsurface community unique to the deep biosphere? Does horizontal spreading of microbes cause the same biogeochemical zones to contain the same 
communities in different oceans, or are there barriers to dispersal?

Genes, cells, populations, and communities: The workshop participants recommended that microscopic observations of sediment and rocks should be expanded to include modern cell staining procedures that maximize biological information. In combination with studies of nucleic acids and organic biomarkers, such direct counts can provide information on the abundance, distribution, and extent of microorganisms in the subseafloor biosphere. Relatively detailed information on microbial populations can be gathered by employing specific microscopic techniques that provide fundamental information about the phylogenetic status and activity of individual cells. Because viral populations have the potential to play important roles in cell death and in horizontal transfer of genes between microorganisms, efforts should also be made to assess the abundance of viruses in both sediment porewater and crustal fluids. Studies of microbial abundance will answer major questions regarding the extent of the subseafloor biosphere, per-cell rates of microbial activities, and the roles of specific populations in major biogeochemical cycles. In addition, with rapid progress in molecular microbial ecology methods, it is now possible to determine the overall genetic potential of microbial communities and to link this potential to specific gene function and expression. This combination of approaches will provide rich information about subseafloor microbial genes, cells, populations, and communities.

Habitability: Subseafloor sediments and crust comprise two of the largest habitats on Earth. Exploring these habitats poses three major challenges for the biogeochemical and geomicrobiological scientific community. The first of these challenges, defining and mapping the limits to habitability in deep subseafloor sediments and crust, was deemed by the breakout group participants to be of highest priority. These limits are set by a variety of physical and chemical properties, such as temperature, availability of energy and nutrients, $\mathrm{pH}$, pressure, water availability, and salinity. Mapping global distributions of physical properties, concentrations, and fluxes of both reductants and oxidants that provide a hospitable environment for microbial activity in the subseafloor ocean should be an obvious product of a concerted scientific drilling effort. The second critical challenge is the detection of life and the consequences of microbial activity, especially in low energy systems. The third challenge is to determine the role of deep subseafloor habitats in biospheregeosphere coupling (e.g., how the subseafloor biosphere affects global biogeochemical cycles). Thorough and quantitative descriptions of key environments, microbial activities, and mass fluxes are required. The geological and biological processes that control transitions in states of habitability and that fuel growth and survival of microbial communities in deep subseafloor environments remain to be determined, but they can be realized through appropriate IODP projects. The opportunity to characterize these transitions with high resolution sampling across a variety of deep subseafloor environments should be pursued by using a broad array of potential microbial signatures-pore water metabolic products, alterations of elemental isotope distributions, enzymatic activities, RNA, and intact polar lipids.

Technology: A number of issues related to technology were discussed. The primary objective was to assure that specific procedures of coring, sample handling, archiving, and routine measurements would be maintained to facilitate microbiological characterization of the deep biosphere. The participants recognized on-going efforts that have been undertaken to facilitate coring and sample handling for study of subseafloor life. Workshop recommendations were intended to build on this existing framework. They included the establishment of an IODP microbiology legacy sampling protocol that would be essential to further studies of the deep biosphere and to facilitate interdisciplinary investigations among IODP scientists. All data generated as part of this legacy sampling should be integrated with the existing IODP database structure, and more microbiological analyses must be added. The IODP is clearly the best vehicle to gain an understanding of the microbial life of the deep biosphere, though appropriate modifications of existing sampling and analytical protocols may be necessary.

Efforts must be made to develop and refine new shipboard and in situ technologies, with one major focus being on CORKs (circulation obviation retrofit kit). CORK technology can provide a platform for culturing active microbial members of the population in situ as well as continual access to subsurface porewater for continuous biogeochemical monitoring of microbial activity within the subseafloor.

\section{Scientific Objectives}

Several major scientific objectives were described by multiple working groups as ideally addressed by IODP capabilities. These include (1) discovering the limits of life and habitability on Earth; (2) determining the extent and nature of deep subseafloor life; (3) identifying the fundamental processes that control the dispersal and evolution of subsurface life; and (4) quantifying the rates and consequences of interactions between the deep subseafloor biosphere and the surface world.

\section{Limits of Life and Habitability on Earth}

There are very few natural environments on Earth's surface where life is absent; however, limits to life are expected in the subsurface world. Consequently, deep drilling of the ocean crust and sediments is uniquely positioned to access and explore the physical and chemical limits to life.

Transitions between states of habitability, as shaped by transitions in environmental properties, are laid out over extensive spatial and temporal scales in the subsurface 


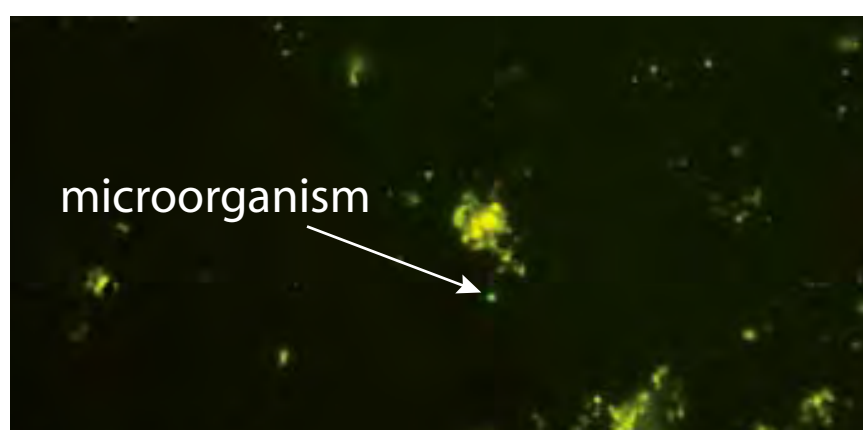

Figure 1. Microorganism from sediment deep beneath the Arctic seafloor (IODP Leg 302). The microbe glows because it has been stained with a fluorescent dye (SYBR Green) that preferentially binds to DNA. Photomicrograph from David C. Smith.

realm. The opportunity to characterize these transitions with high resolution sampling, across a variety of subseafloor environments, is unparalleled for characterizing the fundamental constraints on life. Deep subseafloor drilling is uniquely capable of realizing this potential.

The surface and subsurface realms differ fundamentally in their potential to refine our concept of habitability. The surface world is extensively inhabited. It is characterized by abundant flows of energy. Its uninhabitable spaces are rare. They principally result from dramatic extremes of temperature or aridity, and they typically begin at sharp spatial and temporal transitions from abundantly inhabited spaces. The abrupt aspect of these transitions is incongruent with the nature and resolution of sampling required to refine our sense of habitability and the limits to life. The deep subsurface environment contrasts these characteristics in several respects that offer significant promise for characterizing fundamental constraints on life and habitability. The current state of the art in ocean drilling virtually ensures that the limits of habitability and life will be breached with respect to physical, chemical, and energetic constraints, both individually and in combination. For example, energy flow in subseafloor settings is often orders of magnitude lower than in the surface world (D'Hondt et al., 2002). Subseafloor gradients in environmental conditions and biological states occur over distances that permit highly resolved sampling.

High temperature provides an obvious example of a limit to life and habitability that can be effectively explored through deep-ocean drilling. The presently accepted upper temperature limit for life is $121^{\circ} \mathrm{C}$ (Kashefi and Lovley, 2003), although higher temperature limits have been inferred by a small number of studies. Drilling into subseafloor sediments, igneous rocks, and hydrothermal deposits with temperatures that span the range of $100^{\circ} \mathrm{C}-250^{\circ} \mathrm{C}$ can be used to provide data that may determine upper temperature limits for life.

An additional parameter that undoubtedly limits the occurrence of life is the availability of energy (electron donors and electron acceptors). Subseafloor environments include environments where energy availability is probably too low to maintain life, and environments where life-sus- taining fluxes of electron donors (food) may be independent of photosynthesis and the surface world. In order to characterize these environments, their potential inhabitants, and their control on the occurrence of life, these chemical constraints should be studied in a broad range of environments, including, but not limited to, sediments with very low organic content, deep crustal rocks, and subseafloor regions of active serpentinization.

Environmental limitations on cell density and community complexity may also include the mineralogy of sediments and sub-sediment rocks, interaction between cells and minerals, surface area, porosity and permeability, minimum pore size, and the availability of water.

\section{Extent and Nature of Life in the Deep Subseafloor}

The discovery of a diverse and active subseafloor microbial community in deep sediments and crustal rocks has fundamentally changed our perception of life on Earth, yet, the extent and nature of this subsurface life remains largely unknown. To address this issue, information on the abundance, diversity, and activities of Archaea, Bacteria, Eukarya, and viral populations needs to be elucidated.

Abundance-Microbial cells are widespread and often abundant in subseafloor sediment (Parkes et al., 2000) (Fig. 1), but the geographic distribution, composition, and total biomass of subseafloor life is largely unknown, because major provinces of ocean sediment and crust have never been examined for life, and many categories of organisms (archaea, eukaryotes, viruses) have never been sought in subseafloor samples. Routine microscopic observations of sediment and rocks should be expanded to consistently include direct cell counts. Further information on subseafloor populations can be gathered with microscopic techniques that provide phylogenetic and activity information (such as fluorescent in situ hybridization [FISH], catalyzed reporter deposition [CARD]-FISH, 5-cyano-2,3-ditolyl tetrazolium chloride [CTC], and live/dead staining). To examine viral populations, which have the potential to play important roles in cell death and horizontal gene transfer, efforts should be made to assess their presence in the porewater of sediments (as in Breitbart et al., 2004) and in crustal fluids. Detectable viral populations should be sequenced or tested for an effect on sediment organisms. In addition, efforts to explore the existence and abundance of eukaryotes in sediment and oceanic crust need to be made. The examination of microbial abundance will help answer major questions regarding the extent of the subseafloor and the rate of activity per cell in biogeochemical cycles. These results will serve as a major guide for microbiological investigations of subseafloor sediment and basalt.

Diversity-Microorganisms are the most abundant and diverse life forms on the planet and are the fundamental driv- 
ers of global biogeochemical cycles. Despite their ubiquity, surprisingly little is known about their diversity in the subseafloor, where sediments and basalt are key environments for studying microbial populations and community structures. Many important questions can only be solved by first understanding what microorganisms are present and what functional roles they serve in their communities. Given the combinations of extreme physical and chemical conditions, many of which are only found in the subseafloor (high pressure, low carbon, etc.), this environment is likely to contain assemblages of endemic microorganisms well-adapted to these conditions. Therefore, the subseafloor represents a rich and potentially novel source of genetic material for study and for mining for novel enzymes and enzymes adapted to extreme conditions that can be applied to a wide variety of biotechnological applications.

To understand subseafloor diversity, it will be necessary to conduct surveys of appropriate phylogenetic (16S rRNA genes (Fig. 2) and 18S rRNA genes) and functional gene markers. A variety of methods exist for such microbial diver- sity analyses (denaturing gradient gel electrophoresis (DGGE), terminal restriction fragment length polymorphism (T-RFLP), clone libraries, and tag sequencing); individual investigators should choose the method that is most appropriate based on their specific questions, equipment, and available resources. Unusual and rare microorganisms are to be expected in the deep subsurface, and they may require novel 16S rRNA sequencing approaches for their detection (Sogin et al., 2006). In addition, other markers for phylogenetic diversity should also be considered (e.g., recA, gyrase). While phylogenetic approaches are useful for understanding diversity, they do not provide a direct understanding of function. To better investigate the genetic potential of the subseafloor and the physiological roles of its inhabitants, a suite of investigations would need to be integrated. Molecular approaches include laser capture microdissection (a method for extracting a single cell), which can be coupled to whole genome amplification to map the entire genome of individual cells (Podar et al., 2007). In addition, mRNA amplification for gene expression profiles may be of particular importance for use in low biomass environments.

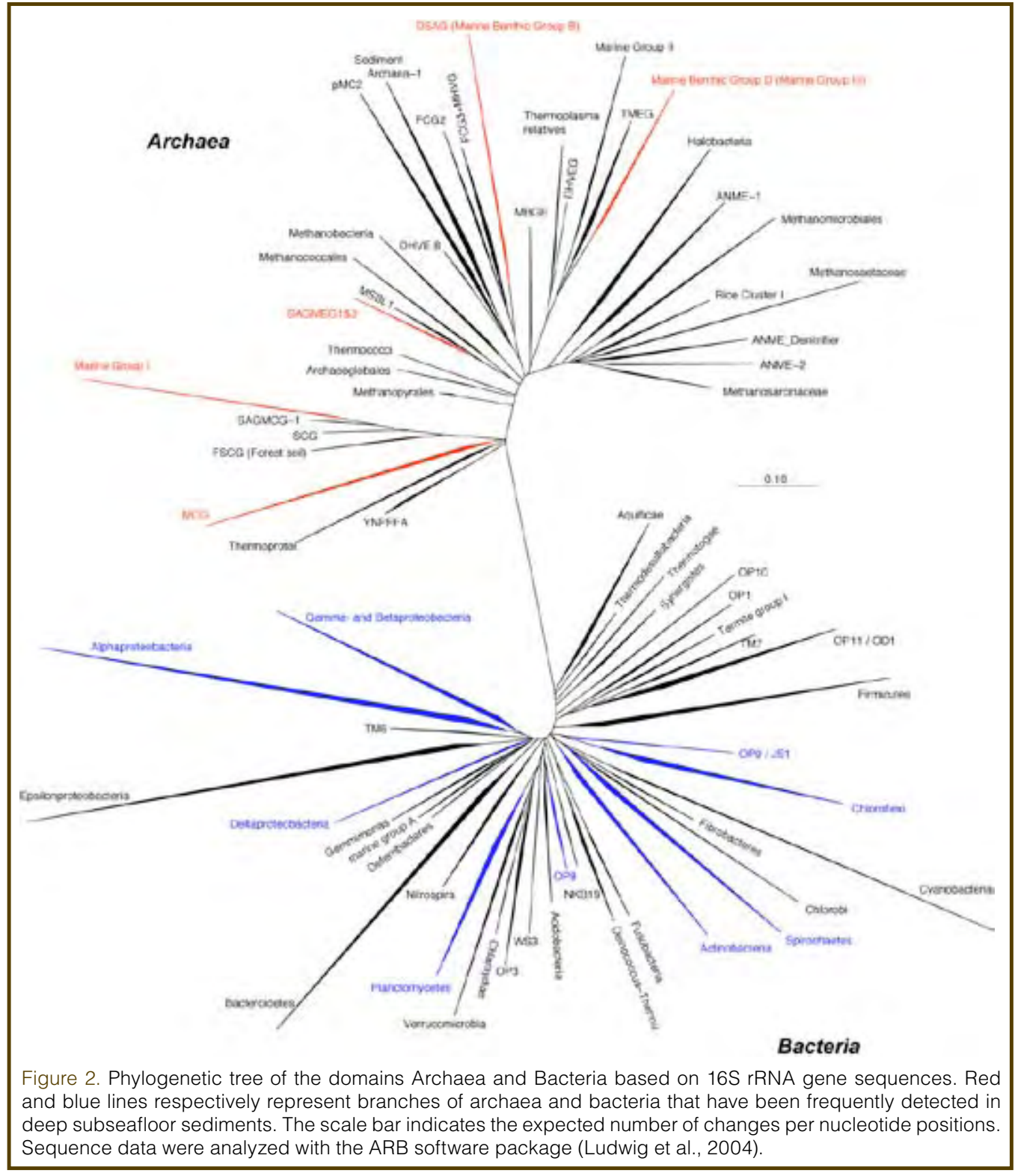

The application of genomic methods to the study of microbial communities directly from the environment (e.g., metagenomics) also represents a range of powerful new approaches. Initial forays into the generation of metagenomic data might best be performed on low diversity environments of at least moderate biomass. This would increase the ability to obtain a larger contiguous sequence from shotgun sequencing and assembly. The creation of genomic libraries also represents an important form of archiving, since these libraries represent a snapshot of the environment from which they were constructed and can be mined by multiple investigators over time.

Metagenomic data, particularly a deep coverage reference metagenome, would create a critical resource for furthering the application of post-genomic methods designed to investigate gene presence or absence (DNA), transcrip- 
tion (mRNA), and translation (protein). For instance, microarray approaches can be applied to determine the presence or absence of genes from a particular region of the subseafloor using comparative genomic hybridizations or to examine gene expression profiles.

Novel culturing methods include those that rely on dilution to extinction in very-low-nutrient media that have been used to obtain bacterial isolates from oligotrophic freshwater (e.g., Crater Lake, Oregon) and marine (e.g., the Sargasso Sea; Rappé et al., 2002) systems and are adaptable to use in studies of subseafloor life. A critical need in environmental microbiology is to elucidate the ecological roles of the most abundant habitat-specific phylogenetic clades. Therefore, cultivation of representative organisms from dominant phylogenetic clades is an important step in initiating additional studies linking diversity with function. Cultured microorganisms are also excellent targets for whole genome sequencing and comparative analyses to aid the creation and data mining efforts of metagenomic and post-metagenomic approaches as well as studies of population genetics.

Activity-IODP can provide access to many biogeochemical regimes within the subseafloor from which a polyphasic approach that incorporates geochemical and molecular techniques should be used to characterize microbial metabolic activities. By extending current shipboard protocols, geochemical analyses of cored sediments can determine concentrations of key terminal electron acceptors (e.g., $\mathrm{NO}_{3 \text {-, }}$ $\left.\mathrm{Fe}(\mathrm{III}), \mathrm{Mn}(\mathrm{IV}), \mathrm{H}_{2}, \mathrm{CO}_{2}, \mathrm{SO}_{4}^{2+}\right)$ and electron donors $\left(\mathrm{CH}_{4}\right.$, $\mathrm{Fe}(\mathrm{II}), \mathrm{H}_{2} \mathrm{~S}$, low molecular weight fatty acids), as well as additional soluble geochemical constituents (isotopic ratios). These data can then serve as guides to specific metabolic processes within the sediment (D'Hondt et al., 2002, 2004; Parkes et al., 2005; Hinrichs et al., 2006) and basalt (Cowen et al., 2003). Molecular assays that target domain level and lineage specific fractions of the population using SSU rRNA genes (DNA-based) and SSU rRNA (RNA-based) can identify the structure of total communities (Inagaki et al., 2006) and metabolically active communities (Sørensen and Teske, 2006), respectively (Fig. 3). Fluorescent in situ hybridization assays that target SSU rRNA molecules within active microbial cells can detect and quantify subsurface microbial populations (Schippers et al., 2005; Biddle et al., 2006). The abundance of functional genes and quantification of enzymes (hydrogenase, phosphatase) can then be utilized to determine the relative activity of specific metabolic pathways that may contribute to local geochemistry. Stable isotope probing (SIP) can also be incorporated to identify carbon utilization, addressing a number of questions including the contribution of heterotrophic versus autotrophic communities within the subsurface. Specific metabolic pathways previously identified within IODP core sediments can therefore be characterized using these and other molecular techniques to identify the lineages responsible for these pathways and begin to address unresolved issues, including but not limited to spa- tial heterogeneity, isolation of subseafloor communities, and horizontal gene flow.

A majority of this microbiological work would be accomplished postcruise. However, efforts will be made to develop and refine new shipboard and in situ technologies. The outcome of both geochemical and molecular measurements will provide a better understanding of the interaction of microbes and their biogeochemical environment, build better biogeochemical models in the oceans, and link surface life and the contribution of subseafloor life to global carbon and other biogeochemical cycles.

\section{Dispersal and Evolution of Subseafloor Life}

Exploration of subseafloor life offers an unmatched opportunity to explore the fundamental processes and mechanisms that have determined and continue to drive the evolution and dispersal of life on Earth.

The fundamental processes that influence the geographic distribution of all life include evolutionary processes that shape the diversity of microbial assemblages through their effects on the growth and death of individuals and populations; dispersal processes that serve to isolate or connect microbial assemblages; and environmental factors that favor winners and losers among the microbes present in a given environment.

Almost nothing is known about how these processes and their consequences play out in the subsurface world. The extent to which subseafloor life is an archive for organisms from the surface world, or a source of genomic, evolutionary, and ecological innovation for the surface world, can be debated. Do evolutionary pressures and mechanisms of microbial dispersal operate differently in the subseafloor communities than in surface communities? Is subseafloor diversity a subset of the diversity in the upper world, or have subseafloor processes of organismal dispersal and environmental selection led to identifiable endemic assemblages? Have novel groups of organisms evolved to take advantage of energy sources that are not commonly considered important in the surface world, such as radiolysis of water, serpentinization reactions, and other subsurface energy sources? Is there selection for or against major metabolic and life history strategies, e.g., metabolic specialization versus a generalism? Can one identify signatures of surface life in subseafloor microbial assemblages, and conversely, can one find evidence that subseafloor life is exported to the surface world?

\section{Geosphere-Biosphere Interactions}

Interactions between the deep subseafloor ecosystem and the geosphere occur on scales from very local to global. These interactions may ultimately affect climate, evolution of the global biosphere, and structure and function of the 


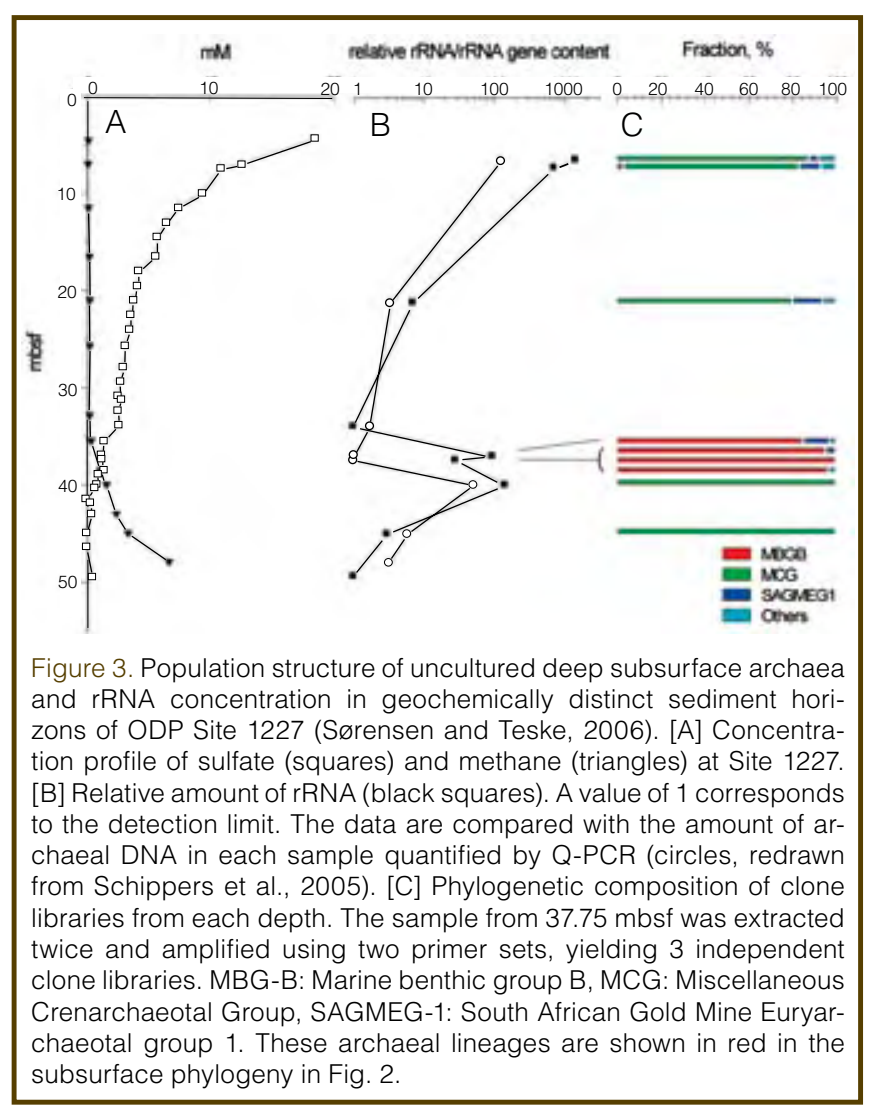

lithosphere. Scientific drilling can address the question of how subseafloor microbial processes and products are related to processes and properties of the overlying surface world (the ocean and the atmosphere). These include, but are not limited to 1) the global balance of oxidants and reductants, 2) the acid-base system of the world ocean, 3) primary productivity uncoupled from the photosynthetic surface world, 4) physical and chemical alteration of deep sediment, and 5) crustal geologic structure.

Scientific drilling of continental margins has demonstrated that massive levels of methane exist along continental margins and may principally be derived from the deep subseafloor biosphere (Fig. 4). Paleoclimatic studies suggest that this energy-rich compound enters the overlying ocean water and the atmosphere and dramatically alters climate. Rates of methanogenesis in deep marine sediments along continental margins are poorly constrained, and recent evidence strongly implicates the important role of microbes in the production of higher hydrocarbons such as ethane and propane (Hinrichs et al., 2006). Another climate driver includes the production and consumption of nutrient compounds. For example, we have no clear idea of the biological fixation, removal, and/or production of nitrogen in deep subseafloor environments. Profiles of dissolved and solid phase $\mathrm{N}$ compounds suggest that these compounds are being cycled in deep subseafloor sediment. The acid-base system of the deep ocean is also subject to deep subseafloor processes. Subseafloor metabolism produces and consumes alkalinity and may have a significant effect on ocean $\mathrm{pH}$ and thus climate. Understanding the overall effect of the subseafloor biosphere on the oceanic acid/base balance (and climate) requires quantification of the net rates of metabolic redox reactions and the factors that control these rates. The redox state of buried carbon and its modification with burial and age as it enters subduction zones have clear implications for global carbon and redox budgets. Exchange of oxidants and reductants between the mantle, crust, and ocean may be significantly altered by deep subsurface processes (Hayes and Waldbauer, 2006). These are all global aspects of coupling of the geosphere and deep subseafloor processes that cause us to ask: what would life in the surface biosphere look like if the deep subsurface biosphere did not exist?

There are numerous potential mechanisms for connecting material and energy flow between deep geosphere processes and life in deep subseafloor environments. On Earth's surface, sunlight overwhelmingly provides the energy for primary productivity; in the subsurface however, the nature of primary productivity is not yet constrained. For example, processes that sustain subsurface primary productivity may be potentially more diverse than those that sustain surface primary productivity, and they may ultimately feed into the ocean-climate system. Because of the high likelihood for abiotic production of hydrogen and simple organic compounds, places where water interacts with ultramafic rock are obvious drilling targets. This type of interaction takes place in a variety of tectonic settings, including rifted continental margins, lava-starved mid-ocean ridge segments, and suprasubduction zone forearcs. The lithosphere community (e.g., 21st Mohole Mission) has a large interest in exploring geodynamic and petrogenetic aspects of these settings. Radiolysis of water may provide a cryptic source of energy for primary production in colder subseafloor environments (Jørgensen and D’Hondt, 2006).

Moreover, the impact of deep sub-surface processes on lithologic properties in crustal and sedimentary environments is largely unknown. Key properties of porosity, permeability, surface area, and the viscosity of interstitial fluids may be significantly altered by sub-surface life processes.

To appreciate the extent and importance of geospherebiosphere interactions in the deep subseafloor, scientific ocean drilling must focus on (1) understanding the processes, pathways, and products of interaction between microbial activity in the subseafloor and the ocean/atmosphere system; (2) elucidating the magnitude and rates of these processes and their ability to influence the environment and climate of the ocean/atmosphere system; and (3) determining the evolution of these interactions over geological time.

\section{Expeditionary Strategies}

The IODP provides a unique facility for studying deep subseafloor life. No other organization provides direct access to deep subsurface environments throughout the world ocean. Nowhere else has a comparable sampling capability 
been developed. Microbiological samples need to be evaluated for contamination by seawater or drilling fluid, as a single cell or DNA molecule might cause erroneous results, and IODP offers essential contamination assessment unlike any other scientific operation. IODP offers a controlled framework for sample handling, archiving, and analysis in microbiology, biogeochemistry, and related disciplines that allows for data integration and cross-sample comparisons. A large set of chemical and physical metadata generated on board is easily integrated into biological experiments. Furthermore, the program provides sites appropriate for long-term in situ experiments on and in the subseafloor, on a broad range of spatial and temporal scales.

Multiple expeditionary strategies will be necessary to explore subseafloor life and habitats. These include (1) single expeditions dedicated to specific subseafloor life objectives; (2) incorporation of dedicated holes or sites into legs scheduled for other purposes (e.g., through an Ancillary Program Letter); (3) participation as a shipboard or shorebased scientist on expeditions scheduled for other purposes; (4) routine measurements and routine archiving of appropriate samples on many or all IODP expeditions; and (5) in special cases, such as required by installation of subseafloor microbial observatories, multi-expedition (multiplatform) projects. In every case, including routine legacy sampling, consideration of microbiological sampling should be an integral part of expedition planning.

\section{Technology Recommendations}

The Ocean Drilling Program (ODP) and the IODP have built a solid framework for occasional study of subseafloor life; however, a number of issues must be addressed to improve studies of deep subseafloor microbial communities and to render such studies routine. The primary objective is to assure that, whenever and wherever possible, coring and sampling handling will facilitate characterization of subseafloor life.

Core recovery (quality and quantity): Coring technology should be optimized to increase quality and, when possible, to increase quantity of material. Advances from industry and from ODP experiments can be leveraged to achieve this goal. Approaches to minimize drilling disturbance and fluid circulation include alteration of existing drilling practices (e.g., use of mud motor, "drilling over" to extend use of hydraulic piston corers to great depth); monitoring activity at the drill bit (to improve quality); bit/shoe redesign; and alteration(s) of core barrel and liners. These changes will greatly enhance the microbiological and biogeochemical value of cored material. For example, they will provide samples of crucial niches at geologic interfaces (e.g., lithologic contacts and fractured materials), and they will improve the rigor and quality of downstream analyses.

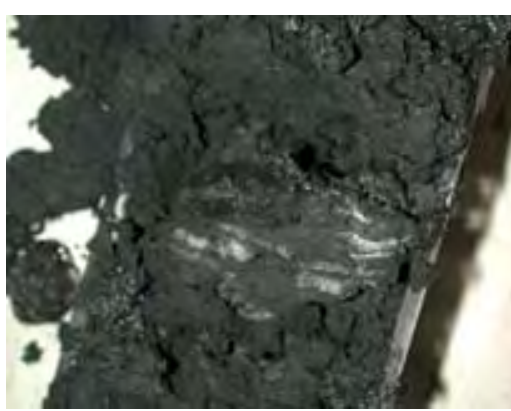

Figure 4. Methane hydrate (white patches) in freshly drilled, organic-rich, methane-supersaturated deep subsurface sediment (Peru Trench, ODP Site 1230, $5086 \mathrm{~m}$ water depth, $96 \mathrm{~m}$ below seafloor).

Diagnostic monitoring of core quality: Quality control issues have been previously addressed with methods to quantify the intrusion of drilling fluid (Smith et al., 2000; House et al., 2003; Lever et al., 2006). Contamination is particularly problematic with igneous samples, and this issue needs to be carefully addressed.

Use of Contamination Tracers-Quantitative contamination tracing should be done on all cores to be used for microbiological study. Existing tracers for monitoring and quantifying contamination [a perfluorocarbon tracer (PFT) and fluorescent beads] have been key components of recent advances in study of subsurface life (Smith et al., 2000; House et al., 2003; Lever et al., 2006), but contamination tracing can and should be greatly improved. Detection limits should be enhanced by further improvement of techniques and by use of a chemical tracer less volatile than the current PFT. Other categories of tracers (e.g., quantum dots) and tools (e.g., 3-D imaging techniques) should be considered to enhance the quality, rigor, and simplicity of analyses. A standardized nucleic acid based method should be developed for monitoring cross-contamination during drilling. The geochemistry and microbiology programs should be directly coupled to monitor gases and contamination tracers.

Onboard handling protocol-Microbiological samples should be aseptically handled and, when appropriate, anaerobically maintained. An appropriate temperature-controlled handling method should be established. Rigorous monitoring of reagents should be conducted.

Personnel-A dedicated, full-time microbiologically trained technician is essential for diagnostic monitoring, archival sampling, and routine measurements. In addition, one or more microbiologists and one or more biogeochemists are needed to maximize scientific return on all cruises.

Maintenance of in situ conditions: As study of subsurface life grows within IODP, the program will need to consider methods for maintaining in situ conditions during coring and sample handling. Many analyses are compromised by depressurization and uncontrolled temperature fluctuations during core retrieval and handling. Core processing should be optimized to minimize changes in temperature, e.g., by recovering cores as quickly as possible and sampling them in a temperature-stabilized environment. IODP should also 
explore methods for insulating the core after removal from the core barrel.

To date, all ocean drilling microbiological samples have undergone depressurization prior to subsampling. Development of sub-sampling tools, or experimental chambers, that can be mated to the pressure coring systems and used to acquire samples or to initiate experiments, is possible. Sensors can be adapted into the design of pressure core barrels to provide time series measurements of important parameters. There may be opportunities for microbiologically relevant spectral measurements using sapphire windows built into the barrels or by changing barrel composition (e.g., aluminum rather than steel) to allow volumetric imaging (X-ray CT, NMR, or PET) for microbial subsampling. However, microbiologists and biogeochemists must identify specific needs and objectives for these experiments before engineering design can be successfully integrated with science requirements.

Sample collection and archiving: Routine collection and preservation of microbiological samples and routine measurements of biological parameters have not been a component of drilling operations. We recommend that a routine sampling program be implemented on all legs and on all three drilling platforms. Microbiological sampling requires specific procedures for core handling that is best accomplished by a dedicated hole.

As an initial step toward this routine program, we recommend an experiment in integrating biodiversity sampling, archiving, and measurements as part of every drilling leg. The development of this database will establish baseline information that could be screened for parameters of interest by individual investigators (porewater chemistry, ocean basin, subseafloor depth, cell density variation, etc.), who could then request samples for the investigator's analysis of choice. A two-year experiment within the IODP that includes a well advertised, clear and straightforward sample request plan is recommended, with the following guidelines.

Requirements for sample handling and sample storage depend on the downstream analyses (see below). The following considerations are pertinent to samples that will be used for shipboard analyses and those that will be shipped to shore-based laboratories or repositories for postcruise studies. Although it is anticipated that most samples will be collected from anaerobic environments, low productivity and/or low carbon environments may be oxygenated, and thus samples should be stored appropriately. In all cases, avoidance and quantification of sample contamination with non-indigenous microbes during drilling and sample handling is of paramount importance.

Biomarker samples-Frozen samples are used for analyzes of nucleic acids, lipid biomarkers, amino acids, etc. These analyses are the central component of biodiversity studies. These samples should be collected as soon as possible and immediately frozen in liquid nitrogen or a $-80^{\circ} \mathrm{C}$ freezer to ensure the safe delivery of samples from the sampling site to the repositories. Samples stored in ultra-low temperature freezers can be maintained in an anaerobic environment by adapting the method of Cragg et al. (1992).

Samples for cultures and activity experiments-Samples that will be used for culture-based isolations and microbial activity measurements should be stored at $4^{\circ} \mathrm{C}$ until analyzed. Samples that are to be used for microbial culturing must be protected from temperature and/or oxygen fluctuations (e. g., samples from an anaerobic environment should be maintained under anaerobic conditions). Samples for anoxic culturing work should be transferred to gas-tight trilaminate bags containing an oxygen scrubber.

Microscopy samples-Samples used for microscopy (e.g., direct cell counts, FISH, microautoradiography) are fixed with aldehydes such as formaldehyde or glutaraldehyde, washed with ethanol:PBS (1:1) solution, and stored at $-20^{\circ} \mathrm{C}$. For FISH-based sample storage it is recommended that samples be preserved according to established protocols (Pernthaler et al., 2002). For these samples, the particular assay dictates the details necessary in the fixation process.

Sample shipping-Because maintaining proper temperature for each category of analysis is essential, samples must be shipped under appropriate temperature conditions (e.g., frozen samples should be shipped in dry ice, and culturing samples should be shipped under $4^{\circ} \mathrm{C}$ refrigeration). A temperature logger should be included in each microbiological or biogeochemical shipping container to provide the thermal history of the samples during transit.

Sample archiving-IODP should establish a repository for routinely collected samples that are collected and stored for subsequent microbiological analysis. The subsamples should be collected as soon as possible after removal from the core in sterile syringes and stored appropriately as described below. This legacy sample should be taken from the middle of the core in near proximity to samples taken for biogeochemical, contamination tracing, and other microbiological analyses.

Standardization of sample-handling protocols-An IODP laboratory protocol book is suggested to help in standardizing procedures and techniques for microbiological sampling, shipping and archiving. This book can be made available electronically on the IODP web site.

Routine Microbiological Measurements: The openly accessible DSDP/ODP/IODP database of routine measurements is a tremendous strength of the scientific drilling program. This allows for continued analysis of the data whether it is using new techniques or global syntheses of data (Parkes et al., 2000; D'Hondt et al., 2002). Therefore, it is necessary to 
institute routine measurements that can be realistically obtained during IODP drilling projects and which provide useful data to assist in the study of subsurface microbiology. All of these data should be made available to the shipboard party via the standard IODP database.

Metabolic products and reactants-Concentrations of some electron acceptors (e.g., dissolved $\mathrm{SO}_{4}^{2-}$ ) and some electron donors (e.g., $\mathrm{CH}_{4}$ ) are already measured routinely as part of the shipboard geochemistry program, which should be expanded to include a much larger range of metabolites. These include, for example, dissolved iron and dissolved manganese in anoxic formation water, and dissolved oxygen and nitrate in the upper sediment column of all sites and above the sediment/basalt interface at open-ocean sites.

Biomass-Biomass quantification should be instituted as a routine measurement.

Total cell counts. Counting of total microbial cells is essential for quantifying subsurface biomass. Each legacy sample for cell counts should be divided in half, with one half counted on ship, and the other preserved and placed at $-20^{\circ} \mathrm{C}$ for comparative counts or more specific quantification on shore. While most ODP/IODP cell counts have been generated using acridine orange direct counts (Cragg et al., 1990), we recommend phasing in the use of a nucleic acid stain with lower background and more stable fluorescence (e.g., SYBR Green) for cell enumeration (Lunau et al., 2005 for sediment analysis; Santelli et al., 2006 for basalt). Total cell counts tend to result in maximum estimates of biomass; however, the detection limit can be reduced by orders of magnitude by separating the cells from the sediment prior to enumeration (Kallmeyer et al., 2006). To standardize cell counts, we suggest that IODP consider adding a flow cytometry instrument to the shipboard laboratory.

As soon as possible, additional methods for assessing biomass should be compared by study of subsamples from multiple sites and cores. Candidate methods include:

(a) Phospholipids. Intact phospholipids can be used to estimate the total microbial biomass and broad community composition in sediment samples (White et al., 1979; Zink et al., 2003). This can be achieved with an HPLC-MS system by quantitative and qualitative analysis of the intact polar membrane lipids, which are diagnostic of live cells (Sturt et al., 2004; Biddle et al., 2006).

(b) ATP. Quantification to estimate active biomass has been used successfully in cores (Egeberg, 2000).

People qualified to undertake these techniques are rare. Members of the IODP community should work to build a pool of expertise sufficient to undertake one or more of these assays during or immediately after most expeditions.
Community composition-Further information on microbial populations can be gathered by using microscopic techniques such as FISH, CARD-FISH, CTC, and live/dead staining, which distinguish different phylogenetic groups and distinguish between active cells and dead or inactive cells. Samples can also be monitored for viruses.

Standardization of laboratory protocols-An IODP handbook is recommended to describe standard microbiological procedures (routine surface decontamination prior to sample handling, biological waste decontamination, etc). The Explanatory Notes from ODP Expedition 201 may serve as a guide for what may be achieved with such a handbook (D'Hondt et al., 2003). As with the suggested microbiology sampling handbook, this book can be made available electronically on the IODP web site.

Technology transfer and data dissemination: Because microbiologists generate some types of samples and data that are unique to their field, some additional issues need to be addressed.

Sequence data-Sequencing of nucleic acids has become the accepted standard method for identifying microorganisms. The usefulness of the data resides in the ability to compare sequences. This is accomplished by submission of sequences to internationally recognized, publicly accessible databases.

Molecular biology offers a suite of tools that provide a powerful strategy for gaining new insights into the diversity of microbial life of the subseafloor. This strategy is particularly powerful when complemented with culture-based methods. The coordinated structure of IODP offers a unique opportunity to explore microbial life in the subseafloor using these integrated approaches. To maximize this opportunity requires capture of genetic data (including sequences of $16 \mathrm{~S}$ rRNA and 18S rRNA genes) from samples collected throughout the program and to make the genetic data available to a wider scientific audience. For this approach to succeed, the provenance of all the genetic information must be catalogued and integrated with the metadata obtained by other IODP efforts (e.g., lithology, geochemistry) in a relational database. To best complete this task, we recommend that the IODP consider building a relational database suitable to the data types collected in this program, as well as exploring interfacing with other repositories of genetic and metadata where feasible and appropriate. Examples of these databases include GenBank, the Ribosomal Database Project (RDP), and CAMERA.

Culture isolates-A common goal for many microbiologists is to obtain pure cultures of microorganisms to perform detailed studies on their physiological capabilities, produce specific enzymes or metabolic byproducts, and so on. It is common practice to place subsamples of the cultures in publicly accessible culture collections. In keeping with the 
open, international cooperation established during the previous decades of scientific ocean drilling, IODP should require that cultures of microorganisms isolated from cores be deposited in a publicly accessible culture collection (Takai et al., 2005). As the program grows and more microbial cultures become available, we recommend that a deep subseafloor culture collection be established. A good example and possible leverage would be to consider a repository in the U.S. Department of Energy's Subsurface Microbial Culture Collection (SMCC).

Microbiological Observatories: In situ experimentation is ultimately the best mechanism for determining in situ processes, including microbial colonization, mineral-microbe interactions and effects of tectonic/volcanic events on subseafloor communities. It is necessary to conduct timeseries and manipulative experiments to constrain the roles, if any, that microorganisms may play in rock alteration and secondary mineral formation. The power of in situ experimentation for studying colonization and mineral alteration has been demonstrated at the seafloor (Edwards et al., 2003, 2004; Edwards, 2004) and in terrestrial systems (Bennett et al., 1996; Edwards et al., 1998; Hiebert and Bennett, 1992). Subseafloor microbiological experiments are now being conducted for the first time as part of the Juan de Fuca hydrogeology experiments made possible by IODP Leg 301 (Fisher et al., 2005; Nakagawa et al., 2006). Similar experiments are proposed for some subsurface life proposals active in the IODP system. Support for CORK operations and technology is imperative for the success of such projects. This includes necessary support for existing technologies, such as the CORK hardware and associated sensors (pressure, temperature, strain and tilt sensors) and samplers (OSMO). Additional in situ capabilities will be necessary to meet future microbiology needs. These needs include samplers and incubators for microbiological analyses, fluid transfer systems, pumping and power systems for seafloor sampling from bore holes, and in situ sensors for key metabolic species, such as hydrogen and methane. Study of active hydrothermal systems will require development of high temperature sampling and technology for in situ measurements. These developments must be supported and encouraged by IODP and governmental funding agencies in IODP countries.

Inclusion of microbiological observatories in IODP proposals requires early identification of critical design specifications. Experimental modules that could be deployed in boreholes will require iterative design efforts by scientists and engineers.

\section{Partnership with Other Organizations}

Study of subseafloor life may provide significant opportunities to partner with industry and government agencies. For example, the U.S. Department of Energy is interested in advanced drilling technology for sampling in high-temperature/high-pressure environments. Such partnerships may require alignment of interests and new models for IODP collaboration and funding. Existing industry tools-such as the modular dynamic (formation) tester (MDT) with a flow control module for fluid sampling across the borehole wall with quality assurance methodology to reduce contamination-may greatly facilitate downhole integration of microbiological and formation fluid sampling. The challenge will be to find ways to deploy these tools in IODP boreholes and work out economic models for their deployment. IODP applications of existing tools may require alternative methods of tool deployment (e.g., wireline reentry, ROV guidance of tools into boreholes, or use of larger-diameter drill pipe) to make the desired measurements.

\section{Acknowledgements}

We thank all of the workshop participants for helping to build a solid community-based foundation for future IODP studies of subsurface life. We particularly thank Kelly Kryc, Holly Given, and the breakout group chairs (Wolfgang Bach, Heribert Cypionka, Katrina Edwards, Philippe Gaillot, Julie Huber, John Parkes and Andreas Teske). Without their efforts, the workshop would not have been a success.

\section{References}

Batzke, A., Engelen, B., Sass, H., and Cypionka, H., 2007. Phylogenetic and physiological diversity of cultured deep-biosphere bacteria from Equatorial Pacific Ocean and Peru Margin sediments. Geomicrobiology J., (in press), doi:10.1016/S00092541(96)00040-X.

Bennett, P.C., Hiebert, F.K., and Choi, W.J., 1996. Microbial colonization and weathering of silicates in a petroleum-contaminated aquifer. Chem. Geol., 132:45-53.

Biddle, J.F., Lipp, J.S., Lever, M.A., Lloyd, K.G., Sorensen, K.B., Anderson, R., Fredricks, H.F., Elvert, M., Kelly, T.J., Schrag, D.P., Sogin, M.L., Brenchley, J.E., Teske, A., House, C.H., and Hinrichs, K.-U., 2006. Heterotrophic Archaea dominate sedimentary subsurface ecosystems off Peru. Proc. Natl. Acad. Sci. U.S.A., 103:3846-3851.

Breitbart, M., Felts, B., Kelley, S., Mahaffy, J.M., Nulton, J., Salamon, P., and Rohwer, F., 2004. Diversity and population structure of a near-shore marine-sediment viral community. Proc. $R$. Soc. Lond. B, 271(1539):565-574, doi:10.1098/ rspb.2003.2628.

Cowen, J.P., Giovannoni, S.J., Kenig, F., Johnson, H.P., Butterfield, D., Rappe, M.S., Hutnak, M., and Lam, P., 2003. Fluids from aging ocean crust that support microbial life. Science, 299:120-123, doi:10.1126/science.1075653.

Cragg, B.A., Parkes, R.J., Fry, J.C., Herbert, R.A., Wimpenny, J.W.T., and Getliff, J.M., 1990. Bacterial biomass and activity profiles within deep sediment layers. In Suess, E., von Huene, R., et al. (Eds.), Proc. ODP, Sci. Res. 112, College Station, Texas (Ocean Drilling Program), 607-619.

Cragg, B.A., Harvey, S.M., Fry, J.C., Herbert, R.A., and Parkes, J.R., 1992. Bacterial biomass and activity in the deep sediment layers of the Japan Sea, Hole 798B. In Pisciotto, K.A., Ingle, 
J.C., Jr., von Breymann, M.T., Barron, J., et al. Proc. ODP, Sci. Res. 127/128 Pt 1, College Station, Texas (Ocean Drilling Program), 761-773.

D’Hondt, S., Jørgensen, B.B., Miller, D.J., Aiello, I.W., Bekins, B., Blake, R., Cragg, B.A., Cypionka, H., Dickens, G.R., Hinnrichs, K.-U., Holm, N., House, C., Inagaki, F., Meister, P., Mitterer, R.M., Naehr, T., Niitsuma, S., Parkes, J., Schippers, A., Skilbeck, C.G., Smith, D.C., Spivack, A.J., Teske, A., Wiegel, J., 2003. Controls on microbial communities in deeply buried sediments, eastern equatorial Pacific and Peru Margin Sites 1225-1231. Proc. ODP, Init. Rep. 201 [CD-ROM]. Available from Ocean Drilling Program, Texas A \& M University, College Station Texas 77845-9547, USA. Web site: http://www-odp.tamu.edu/publications/201_ IR/201ir.htm.

D’Hondt, S., Jorgensen, B.B., Miller, D.J., Batzke, A., Blake, R., Cragg, B.A., Cypionka, H., Dickens, G.R., Ferdelman, T., Hinrichs, K.U., Holm, N.G., Mitterer, R., Spivack, A., Wang, G.Z., Bekins, B., Engelen, B., Ford, K., Gettemy, G., Rutherford, S.D., Sass, H., Skilbeck, C.G., Aiello, I.W., Guerin, G., House, C.H., Inagaki, F., Meister, P., Naehr, T., Niitsuma, S., Parkes, R.J., Schippers, A., Smith, D.C., Teske, A., Wiegel, J., Padilla, C.N., and Acosta, J.L.S., 2004. Distributions of microbial activities in deep subseafloor sediments. Science, 306:22162221, doi :10.1126/science.1101155.

D'Hondt, S., Rutherford, S., and Spivack, A.J., 2002. Metabolic activity of subsurface life in deep-sea sediments. Science, 295:2067-2070, doi:10.1126/science.1064878.

Edwards, K.J., 2004. Formation and degradation of seafloor hydrothermal sulfide deposits. In Amend, J.A., Edwards, K.J., and Lyons, T. (Eds.), Sulfur Biogeochemistry - Past \& Present, Boulder, Colo. (Geological Society of America), 83-96.

Edwards, K.J., Bach, W., McCollom, T.M., and Rogers, D.R., 2004. Neutrophilic iron-oxidizing bacteria in the ocean: habitats, diversity, and their roles in mineral deposition, rock alteration, and biomassproductionin the deep-sea. Geomicrobiology J., 21(6):393-404, doi:10.1080/01490450490485863.

Edwards, K.J., McCollom, T.M., Konishi, H., and Buseck, P.R., 2003. Seafloor bio-alteration of sulfide minerals: results from in situ incubation studies. Geochim. Cosmochim. Acta, 67(15):2843-2856, doi:10.1016/S0016-7037(03)00089-9.

Edwards, K.J., Schrenk, M.O., Hamers, R.J., and Banfield, J.F., 1998. Microbial oxidation of pyrite: Experiments using microorganisms from an extreme acidic environment. Amer. Mineral., 83(12):1444-1453.

Egeberg, P.K., 2000. Adenosine 5'-Triphosphate (ATP) as a proxy for bacteria numbers in deep-sea sediments and correlation with geochemical parameters (Site 994). In Paull, C.K., Matsumoto, R., Wallace, P.J., and Dillon, W.P. (Eds.), Proc. ODP, Sci. Res. 164, College Station, Texas (Ocean Drilling Program), 393-398.

Fisher, A.T., Urabe, T., Klaus, A., and the Expedition 301 Scientists, 2005. Proc. IODP, 301: College Station, Texas (Integrated Ocean Drillig Program Management International, Inc.), doi:10.2204/iodp.proc.301.2005.

Hayes, J.M., and Waldbauer, J.R., 2006. The carbon cycle and associated redox processes through time. Philos. Trans. R. Soc. Lond. B Biol. Sci., 361(1470):931-50, doi:10.1098/ rstb.2006.1840.
Hiebert, F.K., and Bennett, P.C., 1992. Microbial control of silicate weathering in organic-rich ground water. Science, 258:278281, doi:10.1126/science.258.5080.278.

Hinrichs, K.-U., Hayes, J.M., Bach, W., Spivack, A.J., Hmelo, L.R., Holm, N.G., Johnson, C.G., and Sylva, S.P., 2006. Biological formation of ethane and propane in the deep marine subsurface. Proc. Natl. Acad. Sci. U.S.A., 103(40):14684-14689, doi:10.1073/pnas.0606535103.

House, C., Cragg, B., Teske, A., and Party, S.S., 2003. Drilling contamination tests during ODP Leg 201 using chemical and particulate tracers. Proc. ODP Init. Rep..201, College Station, Texas (Ocean Drilling Program), 1-19.

Inagaki, F., Nunoura, T., Nakagawa, S., Teske, A., Lever, M., Lauer, A., Suzuki, M., Takai, K., Delwiche, M., Colwell, F.S., Nealson, K.H., Horikoshi, K., D'Hondt, S., and Jørgensen, B.B., 2006. Biogeographical distribution and diversity of microbes in methane hydrate-bearing deep marine sediments, on the Pacific Ocean Margin. Proc. Natl. Acad. Sci. U.S.A., 103:2815-2820.

Inagaki, F., Suzuki, M., Takai, K., Oida, H., Sakamoto, T., Aoki, K., Nealson, K.H., and Horikoshi, K., 2003. Microbial communities associated with geological horizons in coastal subseafloor sediments from the Sea of Okhotsk. Appl. Environ. Microbiol., 69:7224-7235, doi:10.1073/pnas.0511033103.

Jørgensen, B.B., and D'Hondt, S., 2006. A starving majority deep beneath the seafloor. Science, 314:932-943, doi:10.1126/science.1133796.

Kallmeyer, J., Anderson, R., Smith, D.C., Spivack, A.J., and D’Hondt, S., 2006. Separation of microbial cells from deep sediments, NASA Astrobiology Institute Biennial Meeting 2005. Astrobiology, 6(1):271.

Kashefi, K., and Lovley, D.R., 2003. Extending the upper temperature limit for life. Science, 301:934, doi:10.1126/science.1086823.

Lever, M.A., Alperin, M., Engelen, B., Inagaki, F., Nakagawa, S., Steinsbu, B.O., Teske, A., and IODP Expedition 301 Shipboard Scientific Party, 2006. Trends in basalt and sediment core contamination during IODP Expedition 301. Geomicrobiology J., 23:517-530, doi:10.1080/0149045060089 7245.

Ludwig, W., Strunk, O., Westram, R., Richter, L., Meier, H., Yadhukumar, Buchner, A., Lai, T., Steppi, S., Jobb, G., Förster, W., Brettske, I., Gerber, S., Ginhart, A.W., Gross, O., Grumann, S., Hermann, S., Jost, R., König, A., Liss, T., Lüßmann, R., May, M., Nonhoff, B., Reichel, B., Strehlow, R., Stamatakis, A., Stuckmann, N., Vilbig, A., Lenke, M., Ludwig, T., Bode, A., and Schleifer, K.-H., 2004. ARB: a software environment for sequence data. Nucleic Acids Res. 32:1363-1371, doi: 10.1093/nar/gkh293.

Lunau, M., Lemke, A., Walther, K., Martens-Habbena, W., and Simon, M., 2005. An improved method for counting bacteria from sediments and turbid environments by epifluorescence microscopy. Environ. Microbiol., 7:961-968, doi:10.1111/ j.1462-2920.2005.00767.x.

Nakagawa, S., Inagaki, F., Suzuki, Y., Steinsbu, B.O., Lever, M.A., Takai, K., Engelen, B., Sako, Y., Wheat, C.G., Horikoshi, K., and Integrated Ocean Drilling Program Expedition 301 Scientists, 2006. Microbial communities in black rust exposed to hot ridge-flank crustal fluids. Appl. Environ. Microbiol., 72:6789-6799, doi:10.1128/AEM.01238-06. 
Parkes, R.J., Cragg, B.A., and Wellsbury, P., 2000. Recent studies on bacterial populations and processes in subseafloor sediments: A review. Hydrogeol. J., 8:11-28, doi:10.1007/ PL00010971.

Parkes, R.J., Webster, G., Cragg, B.A., Weightman, A.J., Newberry, C.J., Ferdelman, T.G., Kallmeyer, J., Jørgensen, B.B., Aiello, I.W., and Fry, J.C., 2005. Deep sub-seafloor prokaryotes stimulated at interfaces over geological time. Nature, 436:390-394, doi:10.1038/nature03796.

Pernthaler, A., Pernthaler, J., and Amann, R., 2002. Fluorescence in situ hybridization and catalyzed reporter deposition (CARD) for the identification of marine bacteria. Appl. Environ. Microbiol., 68:3094-3101, doi:10.1128/AEM.68.6.30943101.2002.

Podar, M., Abulencia, C.B., Walcher, M., Hutchison, D., Zengler, K., Garcia, J.A., Holland, T., Cotton, D., Hauser, L., and Keller, M., 2007. Targeted access to the genomes of low-abundance organisms in complex microbial communities. Appl. Environ. Microbiol., 73:3205-3214, doi:10.1128/AEM.0298506.

Rappé, M.S., Connon, S.A., Vergin, K.L., and Giovannoni, S.J., 2002. Cultivation of the ubiquitous SAR11 marine bacterioplankton clade. Nature, 418:630-633, doi:10.1038/nature00917.

Reed, D.W., Fujita, Y., Delwiche, M.E., Blackwelder, D.B., Sheridan, P.P., Uchida, T., and Colwell, F.S., 2002. Microbial communities from methane hydrate-bearing deep marine sediment in a forearc basin. Appl. Environ. Microbiol., 68:3759-3770, doi:10.1128/AEM.68.8.3759-3770.2002.

Santelli, C.M., Edgcomb, V., Bach, W., and Edwards, K.J., 2006. Diversity of endolithic bacteria in seafloor basalt. European Geosciences Union (EGU) Meeting, Vienna, Austria, 3 April 2006 (Poster Presentation).

Schippers, A., Neretin, L.N., Kallmeyer, J., Ferdelman, T.G., Cragg, B.A., Parkes, J.R., and Jørgensen, B.B., 2005. Prokaryotic cells of the deep sub-seafloor biosphere identified as living bacteria. Nature, 433:861-864, doi:10.1038/nature03302.

Smith, D.C., Spivack, A.J., Fisk, M.R., Haveman, S.A., Staudigel, H., and Shipboard Scientific Party, 2000. Tracer-based estimates of drilling-induced microbial contamination of deep sea crust. Geomicrobiology J. 17:207-219. doi:10.1080/01490 450050121170.

Sogin, M.L., Morrison, H.G., Huber, J.A., Welch, D.M., Huse, S.M., Neal, P.R., Arrieta, J.M., and Herndl, G.J., 2006. Microbial diversity in the deep sea and the under explored "rare biosphere”. Proc. Natl. Acad. Sci. U.S.A., 103:12115-12120, doi:10.1073/pnas.0605127103.

Sorensen, K.B., and Teske, A., 2006. Stratified communities of active archaea in deep marine subsurface sediments. Appl. Environ.Microbiol.,72:4596-4603, doi:10.1128/AEM.0056206.

Sturt, H.F., Summons, R.E, Smith, K., Elvert, M., and Hinrichs, K.U., 2004. Intact polar membrane lipids in prokaryotes and sediments deciphered by high-performance liquid chromatography/electrospray ionization multistage mass spectrometry - new biomarkers for biogeochemistry and microbial ecology. Rap. Comm. Mass Spec., 18:617-628, doi:10.1002/ rcm.1378.

Takai, K, Moyer, C.L., Miyazaki, M., Nogi, Y., Hirayama, H., Nealson, K.H., and Horikoshi, K., 2005. Marinobacter alkaliphilus sp. nov., a novel alkaliphilic bacteriumm isolated from subseafloor alkaline serpentine mud from Ocean Drilling Program (ODP) Site 1200 at South Chamorro Seamount, Mariana Forearc. Extremophiles, 9:17-27, doi:10.1007/ s00792-004-0416-1.

Teske, A., 2006. Microbial communities of deep marine subsurface sediments: molecular and cultivation surveys. Geomicrobiology J., 23:357-368, doi:10.1080/0149045060087 5613.

Webster, G., Parkes, R.J., Cragg, B.A., Newberry, C.J., Weightman, A.J., and Fry,J.C., 2006. Prokaryotic community composition and biogeochemical processes in deep subseafloor sediments from the Peru Margin. FEMS Microbiol. Ecol., 58:65-85, doi:10.1111/j.1574-6941.2006.00147.x.

White, D.C., Davies, W.M., Nickels, J.S., King, J.D., and Bobbie, R.J., 1979. Determination of the sedimentary microbial biomass by extractable lipid phosphate. Oecologia, 40:51-62, doi:10.1007/BF00388810.

Whitman, W.B., Coleman, D.C., and Wiebe, W.J., 1998. Prokaryotes: The unseen majority. Proc. Natl. Acad. Sci. U.S.A., 95:65786583, doi:10.1073/pnas.95.12.6578.

Zink, K.G., Wilkes, H., Disko, U., Elvert, M., and Horsfield, B., 2003. Intact phospholipids - microbial "life markers" in marine deep subsurface sediments. Organic Geochem., 34:755-769, doi:10.1016/S0146-6380(03)00041-X.

\section{Authors}

Steven D'Hondt, Graduate School of Oceanography, University of Rhode Island, Narragansett Bay Campus, South Ferry Road, Narragansett, R.I. 02882, U.S.A., e-mail: dhondt@gso.uri.edu.

Fumio Inagaki, Kochi Institute for Core Sample Research, Japan Agency for Marine-Earth Science and Technology (JAMSTEC), B200 Monobe, Nankoku, Kochi, 783-8502, Japan.

Timothy Ferdelman, Max Planck Institute (MPI) for Marine Microbiology, Celsiusstr. 1, D-28359, Bremen, Germany.

Bo Barker Jørgensen, Max Planck Institute (MPI) for Marine Microbiology, Celsiusstr. 1, D-28359, Bremen, Germany.

Kenji Kato, Department of Geosciences, Faculty of Science, Shizuoka University, Shizuoka, 422-8529, Japan.

Paul Kemp, Center for Microbial Oceanography: Research and Education, 1000 Pope Road, Marine Sciences Builiding, Honolulu, Hawaii 96822, U.S.A.

Patricia Sobecky, School of Biology, Georgia Institute of Technology, Atlanta, Ga. 30332, U.S.A.

Mitchell Sogin, Marine Biological Laboratory, $7 \mathrm{MBL}$ Street, Woods Hole, Mass., 02513-1015, U.S.A.

Ken Takai, Subground Animalcule Retrieval Program, Extremobiosphere Research Center, Japan Agency for Marine-Earth Science and Technology (JAMSTEC), 2-15 Natsushima-cho, Yokosuka, Kanagawa, 237-0061, Japan. 